\title{
Article \\ Biodegradability of Novel Polylactide and Polycaprolactone Materials with Bacteriostatic Properties Due to Embedded Birch Tar in Different Environments
}

\author{
Agnieszka Richert $^{1, * \mathbb{D}}$, Agnieszka Kalwasińska ${ }^{2} \mathbb{D}$, Maria Swiontek Brzezinska ${ }^{2}$ and Grażyna B. Dąbrowska ${ }^{1}$ \\ 1 Department of Genetics, Faculty of Biology and Veterinary Science, Nicolaus Copernicus University in Torun, \\ Lwowska 1, 87-100 Toruń, Poland; browsk@umk.pl \\ 2 Department of Environmental Microbiology, Faculty of Biology and Veterinary Science, Nicolaus Copernicus \\ University in Toruń, Lwowska 1, 87-100 Toruń, Poland; kala@umk.pl (A.K.); swiontek@umk.pl (M.S.B.) \\ * Correspondence: a.richert@umk.pl; Tel.: +48-566-114-576
}

check for

updates

Citation: Richert, A.; Kalwasińska,

A.; Brzezinska, M.S.; Dąbrowska, G.B.

Biodegradability of Novel Polylactide and Polycaprolactone Materials with Bacteriostatic Properties Due to Embedded Birch Tar in Different Environments. Int. J. Mol. Sci. 2021, 22, 10228. https://doi.org/10.3390/ ijms221910228

Academic Editor: Piotr Dobrzynski

Received: 10 August 2021

Accepted: 19 September 2021

Published: 23 September 2021

Publisher's Note: MDPI stays neutral with regard to jurisdictional claims in published maps and institutional affiliations.

Copyright: (c) 2021 by the authors. Licensee MDPI, Basel, Switzerland. This article is an open access article distributed under the terms and conditions of the Creative Commons Attribution (CC BY) license (https:/ / creativecommons.org/licenses/by/ $4.0 /)$.

\begin{abstract}
The microbial biodegradation of new PLA and PCL materials containing birch tar (1-10\% $v / v$ ) was investigated. Product of dry distillation of birch bark (Betula pendula Roth) was added to polymeric materials to obtain films with antimicrobial properties. The subject of the study was the course of enzymatic degradation of a biodegradable polymer with antibacterial properties. The results show that the type of the material, tar concentration, and the environment influenced the hydrolytic activity of potential biofilm degraders. In the presence of PCL films, the enzyme activities were higher (except for $\alpha$-D-glucosidase) compared to PLA films. The highest concentration of birch $\operatorname{tar}(10 \% v / v)$ decreased the activity of hydrolases produced by microorganisms to the most significant extent; however, SEM analysis showed the presence of a biofilm even on plastics with the highest tar content. Based on the results of the biological oxygen demand (BOD), the new materials can be classified as biodegradable but, the biodegradation process was less efficient when compared to plastics without the addition of birch tar.
\end{abstract}

Keywords: biofilm; biodegradable films; birch tar; polycaprolactone; polylactide

\section{Introduction}

There are many biodegradable polymer materials such as starch, cellulose, lignin, or aliphatic polyesters such as polylactide (PLA), poly ( $\varepsilon$-caprolactone) (PCL) or poly (3-hydroxybutyric acid), obtained from renewable raw materials, which is of great importance in the age of fossil fuel depletion and the increasing problems with disposal of plastics. Among the materials listed above, the most important are polylactide (PLA) and polycaprolactone (PCL). They are relatively easily decomposed by microorganisms [1,2] and can be readily modified, which makes them more attractive than other materials. To protect the product against harmful microorganisms, various antimicrobial substances are introduced or applied to the polymeric materials, e.g., sorbic acid, benzoic acid, triclosan, grapefruit seed extract, lysozyme, and bacteriocins [3-6]. There are also many studies showing the use of volatile substances such as thymol, carvacrol [7-10], or nanoparticles, e.g., nanosilver [6,11,12], to obtain materials with bactericidal properties. Since 2013, more than 27,845 patents for antimicrobial polymers have been filed in the Google Patent Search database. In addition, antibacterial medical devices have attracted considerable attention in clinical trials [13]. Tar, a product of dry wood distillation, has been known for centuries and is used today in a variety of industrial sectors, mainly in cosmetics and pharmaceuticals $[14,15]$. This dark brown, thick liquid was used in the past to lubricate wooden gears, wheel hubs of carts and carriages, and to impregnate ("dressing") buckskin leathers [16]. Recent studies suggest that tar was chewed in the Neolithic age to alleviate toothache $[15,17]$. Nowadays, purified and distilled tar is used in dermatology as an aseptic. It is used in the form of ointments and alcohol solutions in the treatment of skin diseases 
of humans and animals [18]. The suitability of birch tar oil as either a biocide, repellent against insects, weeds, and rodents, or in both, has also been documented [19-21]. Recently, attempts were made to use tar to protect plants against bacterial and fungal diseases [22-25] and to combat snails [26]. Biodegradation is defined as the breakdown of organic chemicals, including pollutants, into innocuous products such as $\mathrm{CO}_{2}, \mathrm{CH}_{4}$ and $\mathrm{H}_{2} \mathrm{O}$ by the action of microorganisms including archaea, bacteria and fungi. It depends on the activity of various enzymes. According to Zhuikov et al., (2021) [27], enzymatic degradation is found to significantly accelerate the degradation rate of PLA I PHB compared to non-enzymatic hydrolytic degradation. The first reported PLA-degrading enzyme was proteinase K from Tritirachium album $[28,29]$. Chemical modification of packaging materials is not always a preferred strategy in pollutant management and remediation as it may inhibit degradation by acting on the cells of microorganisms and their enzymes, particularly if the substance is of a strong biocidal nature and shows inhibitory activity towards biocatalysts. Environment conditions such as the content of organic matter, availability of elements, temperature, $\mathrm{pH}$, and oxygen, influence the abundance of microorganisms and their metabolism, which determines the rate of biodegradation. Therefore, it is important to assess biodegradation of modified polymers thoroughly and especially under conditions stimulating those found in the natural environment.

The aim of this study was to demonstrate the biodegradability of new polylactide and polycaprolactone materials with embedded birch tar as biocidal substance in water and in soil environments. The subject of the study was the course of enzymatic degradation of a biodegradable polymer with antibacterial properties. We assume that PLA and PCL films, despite the presence of this antibacterial agent, will constitute a new type of biodegradable and cheap-to-produce ecological material that will be used in many industries.

\section{Results}

\subsection{Description of the Produced Materials—Visual and Microscopic Analysis (SEM)}

A method of obtaining PLA and PCL films with the addition of birch tar has been developed. The increase in the tar content resulted in an increase in the color intensity of the foil (Figure 1). The films with $1 \%$ tar content were gray-brown in color, $5 \%$ content of this substance gave the film a light-brown color, and $10 \%$ of the addition of this substance made the films intensely brown.

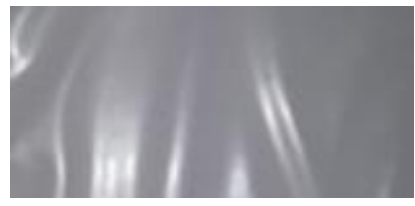

PLA

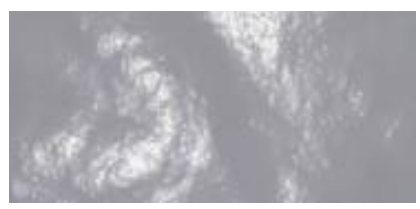

PCL

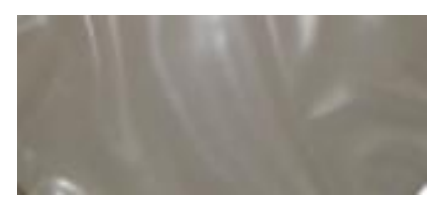

PLA-B1

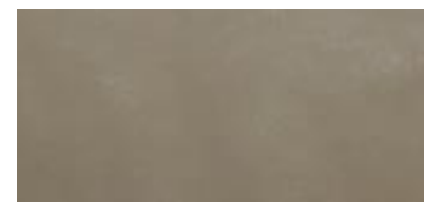

PCL-B1

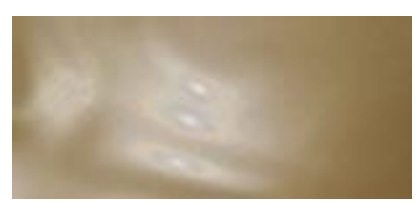

PLA-B5

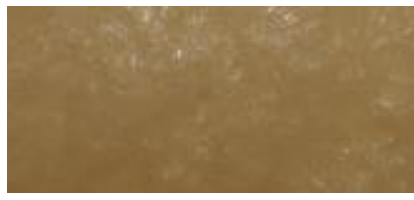

PCL-B5

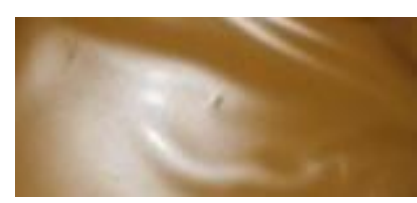

PLA-B10

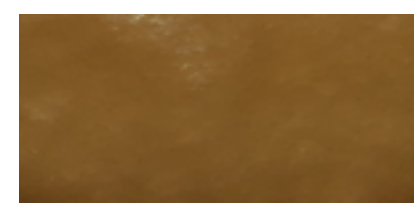

PCL-B10

Figure 1. The appearance of the PLA and PCL films without and with birch tar.

Our research is aimed at the pursuit of new materials which have the ability to prevent bacteria from attaching themselves to polymeric surfaces. One of the possibilities is to obtain an antibacterial surface by introducing a biocidal agent into the polymer matrix. Figures 2 and 3 show the surface morphology of the investigated surfaces. 
(A)

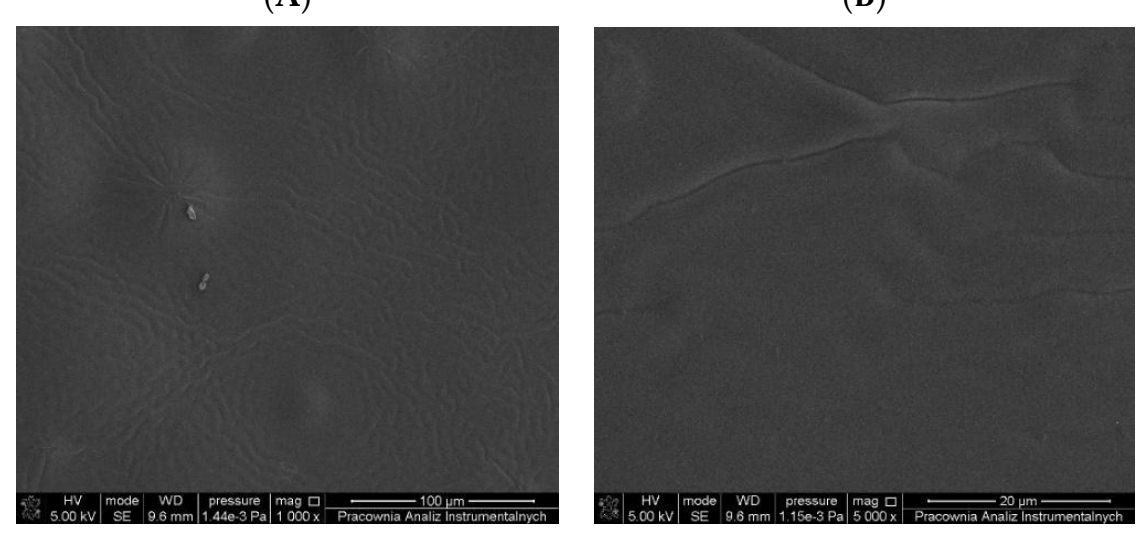

PLA

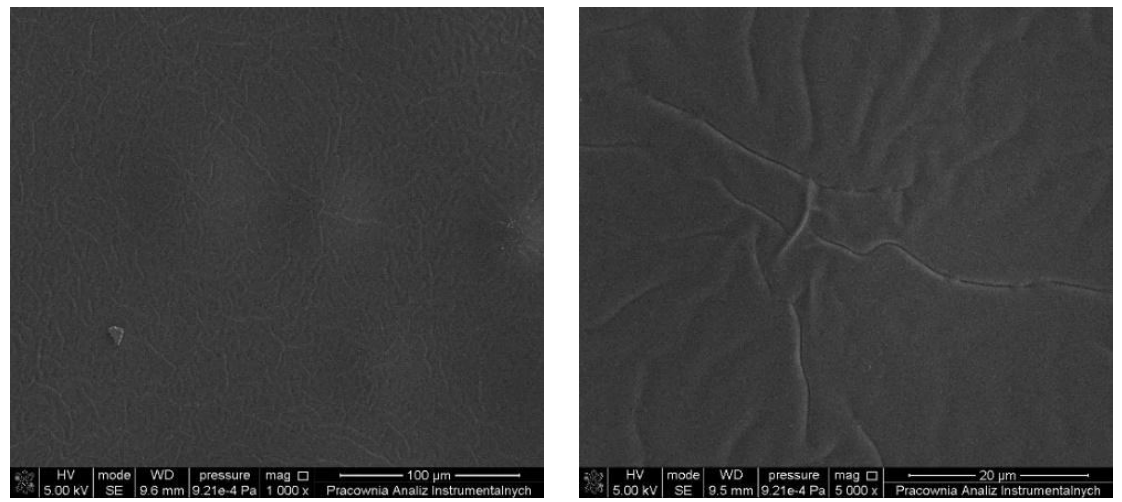

PLA-B1

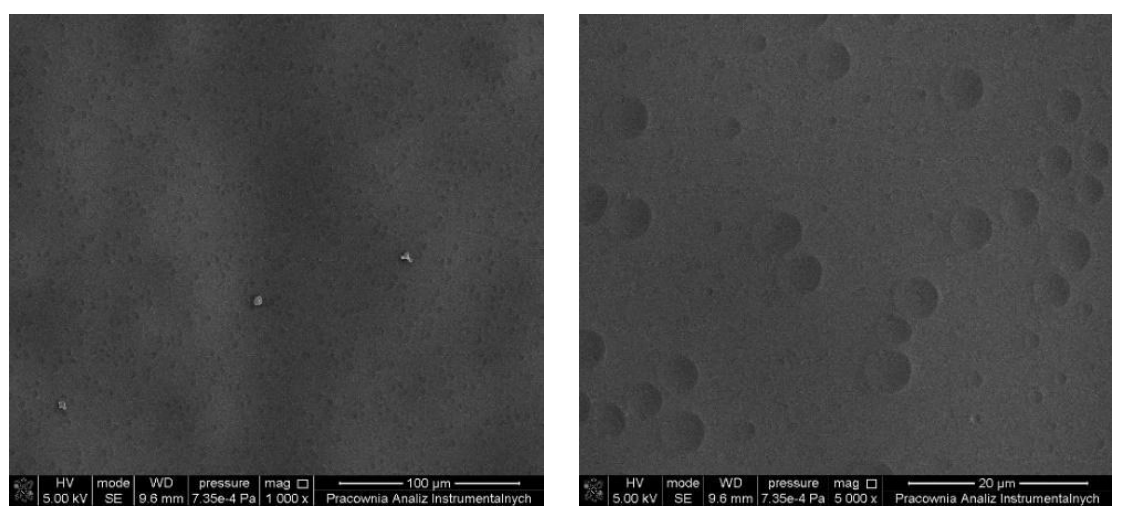

PLA-B5

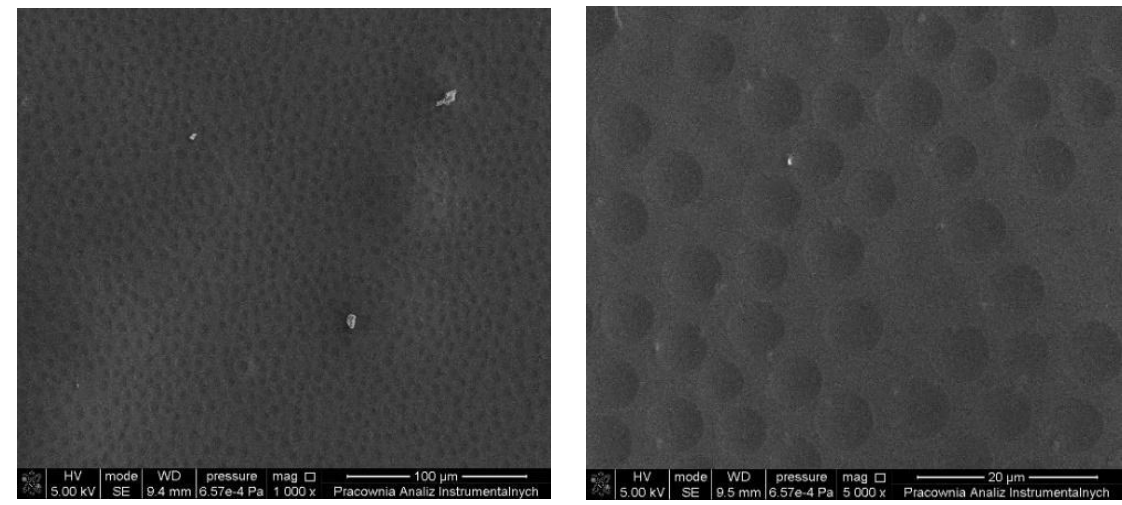

PLA-B10

Figure 2. SEM analysis of surface of PLA and PLA with birch tar (PLA-B1-PLA-B10) materials, magnifications of $1000 \times(\mathbf{A})$ and $5000 \times(B)$. 
(A)
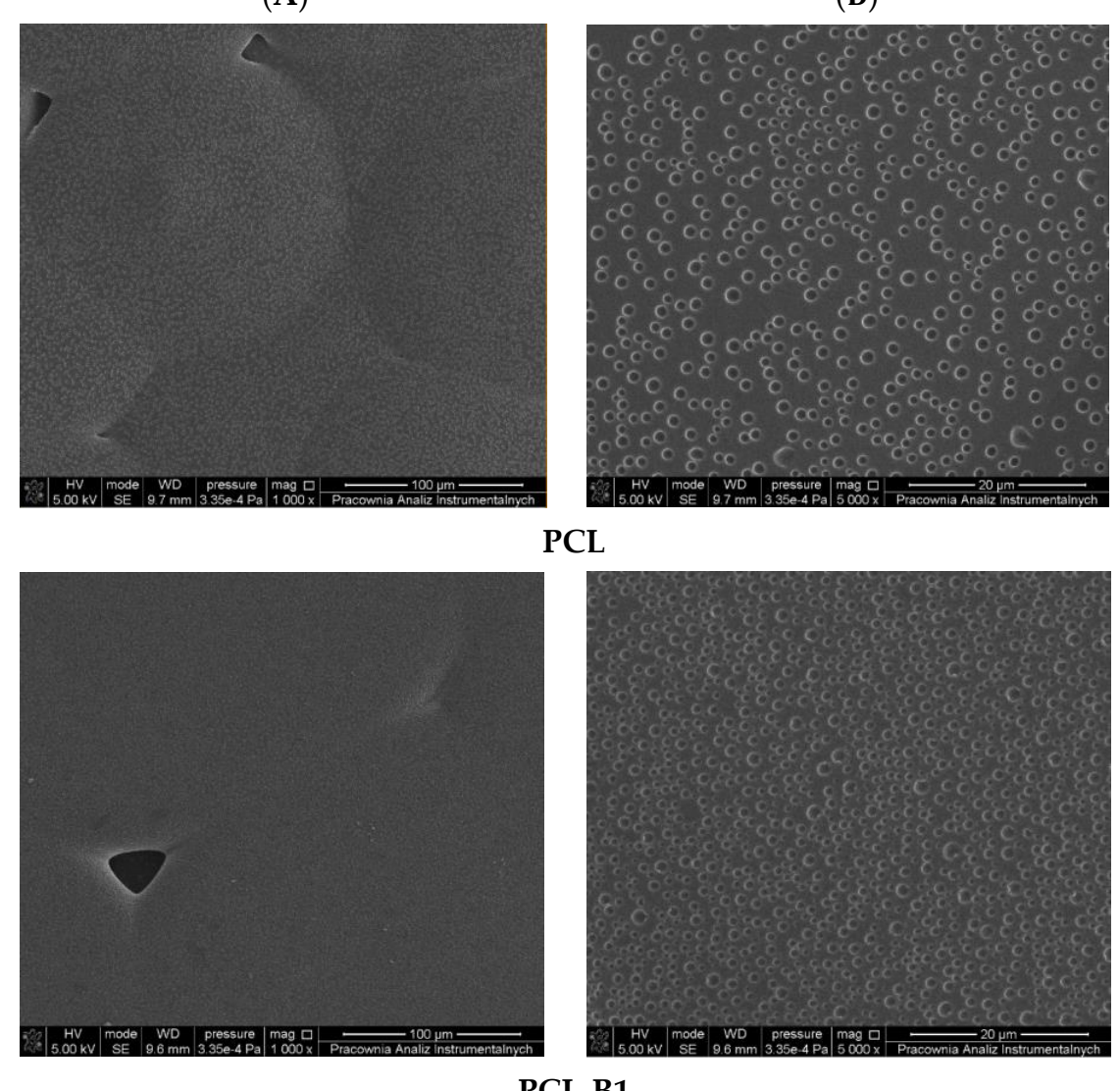

PCL-B1

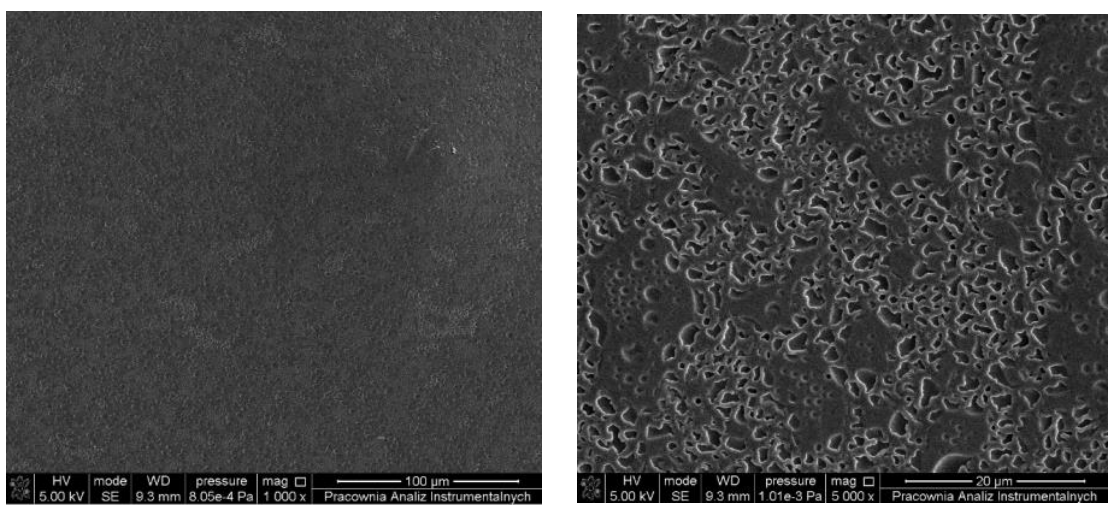

PCL-B5

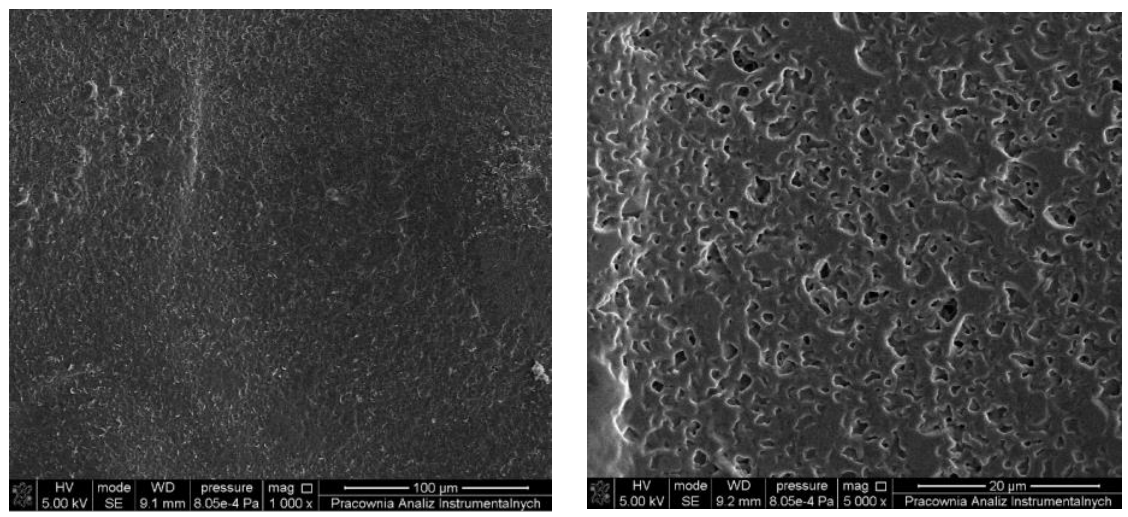

PCL-B10

Figure 3. SEM analysis of surface of PCL and PCL with birch tar (PCL-B1-PCL-B10) materials, magnifications of $1000 \times(\mathbf{A})$ and $5000 \times(B)$. 
In Figures 2 and 3 SEM images of the studied PLA and PCL-based materials were shown. As can be observed, the material consisting of polylactide with an addition of plasticizer in the form of poly(ethylene glycol) is characterized by a rippled surface with irregularities indicating limited miscibility of the used polymers.

\subsection{The Impact of Microorganisms from Various Environments on Materials Containing Birch Tar}

Biological oxygen demand, biofilm, and enzymatic activity analyses were performed to demonstrate biodegradation changes.

\subsubsection{Biological Oxygen Demand}

To assess the biodegradability of PLA and PCL materials, biochemical oxygen demand was measured in water and soil in the presence of those materials (Figure 4).
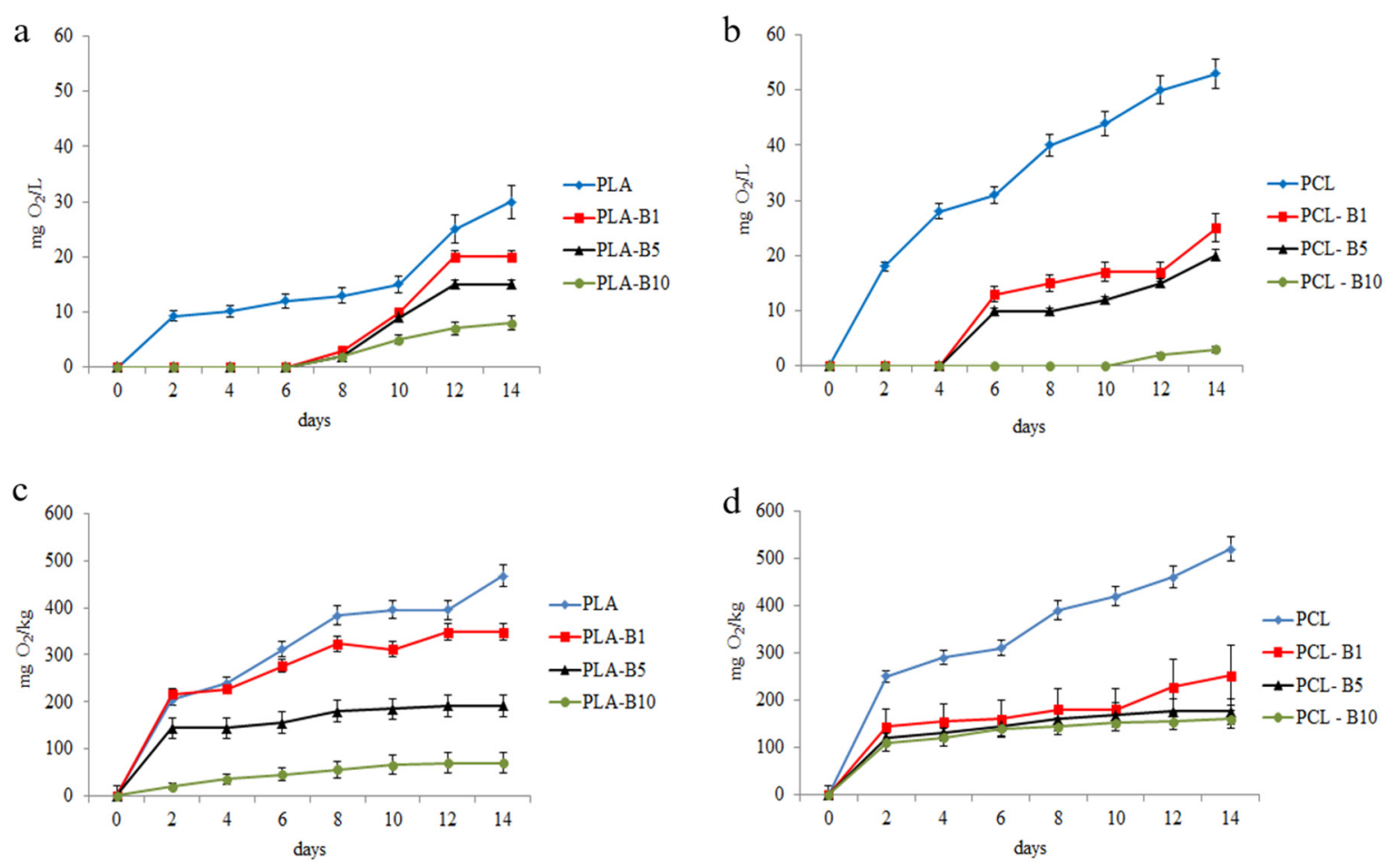

Figure 4. Biological oxygen demand (BOD7) in river water $(\mathbf{a}, \mathbf{b})$ and soil $(\mathbf{c}, \mathbf{d})$ in the presence of polymers; values are expressed as mean $\pm \mathrm{SD}(n=3)$.

It was shown that water microorganisms were characterized by higher metabolic activity (higher oxygen demand) in the presence of PCL, compared to PLA. The same tendency was observed for soil (Figure 4). BOD values obtained for soil were 10 times higher than in water. BODs from soil and water were also lower in the presence of polymers containing birch tar than in the presence of PCL and PLA without modifications. That means that birch tar reduces the rate of biodegradation. Water and soil microorganism are able to colonize materials which contain birch tar at the concentration of $1-10 \%$.

\subsubsection{Biofilm Analysis Using SEM}

In order to analyze the surface morphology of the obtained polymeric films, scanning electron microscopy was applied. In Figure 5, SEM images of the studied PLA-based materials are shown. 


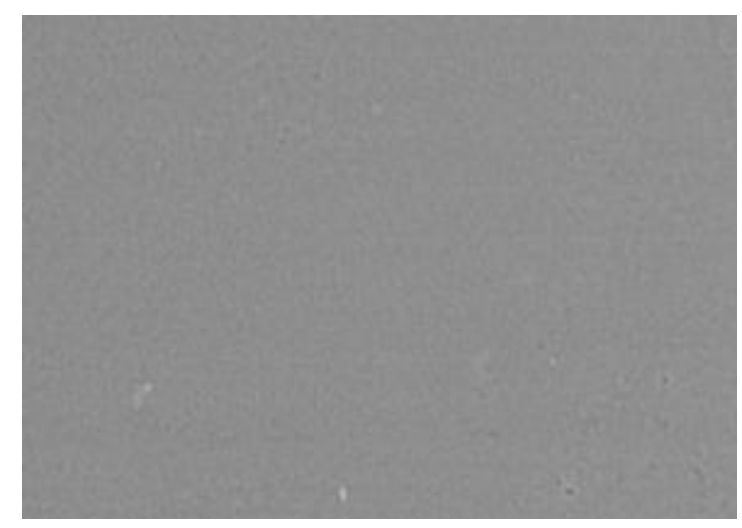

(a) PLA before incubation in water or soil
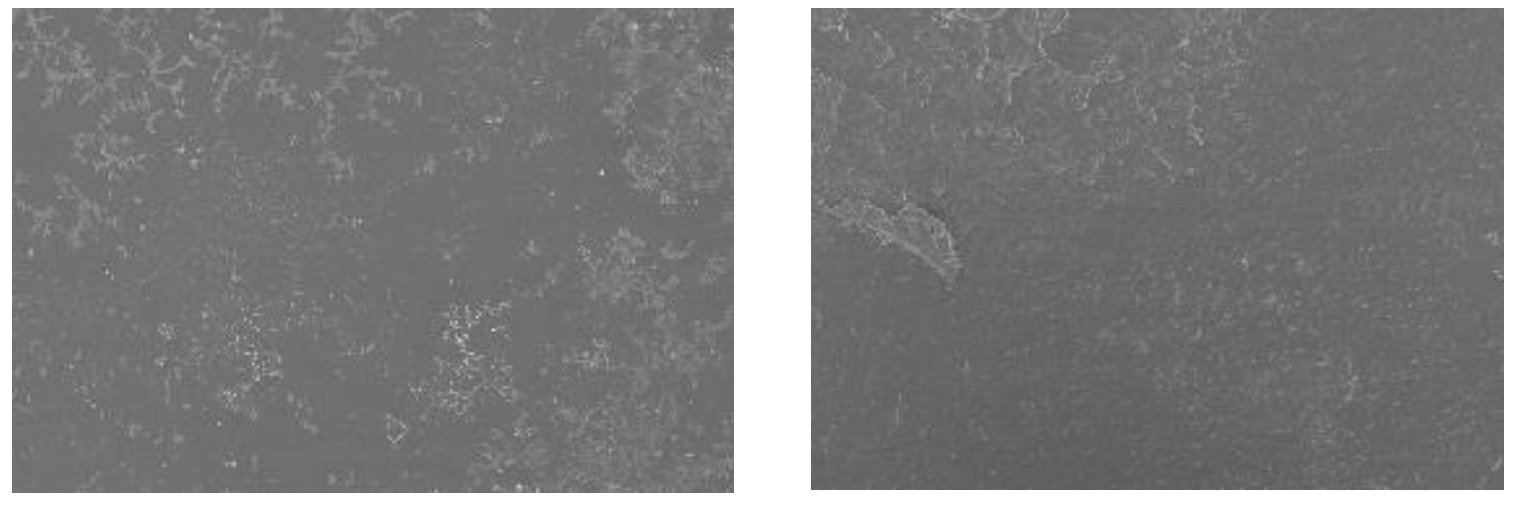

(b) PLA water

$50 \mu \mathrm{m}$
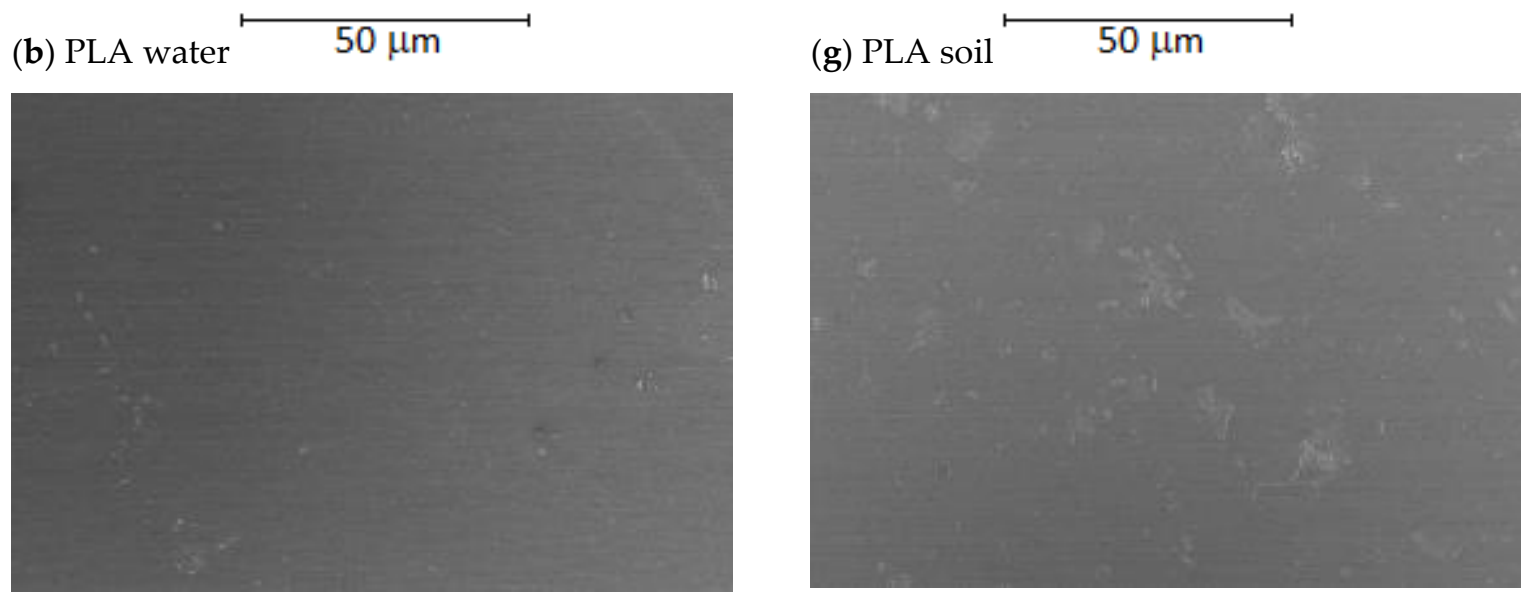

(c) PLA-B10 water

$50 \mu \mathrm{m}$

(h) PLA-B10 soil

$50 \mu \mathrm{m}$

Figure 5. Cont. 
(d) PCL before incubation in water or soil
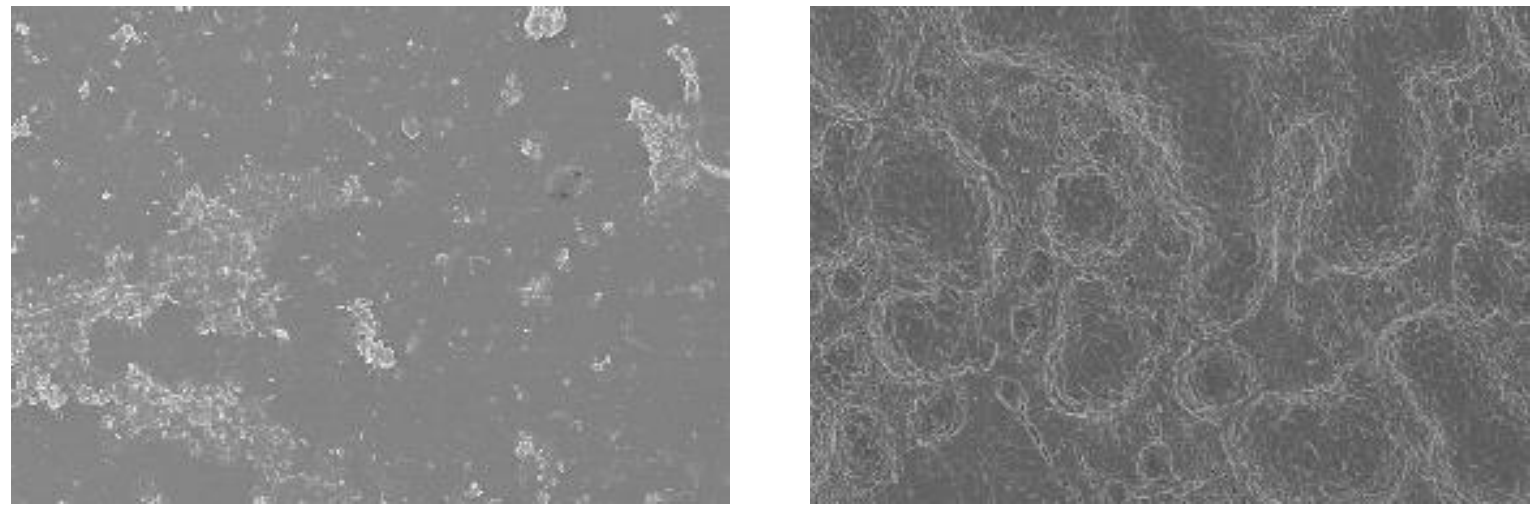

(e) PCL water

$50 \mu \mathrm{m}$

(i) PCL soil

$50 \mu \mathrm{m}$
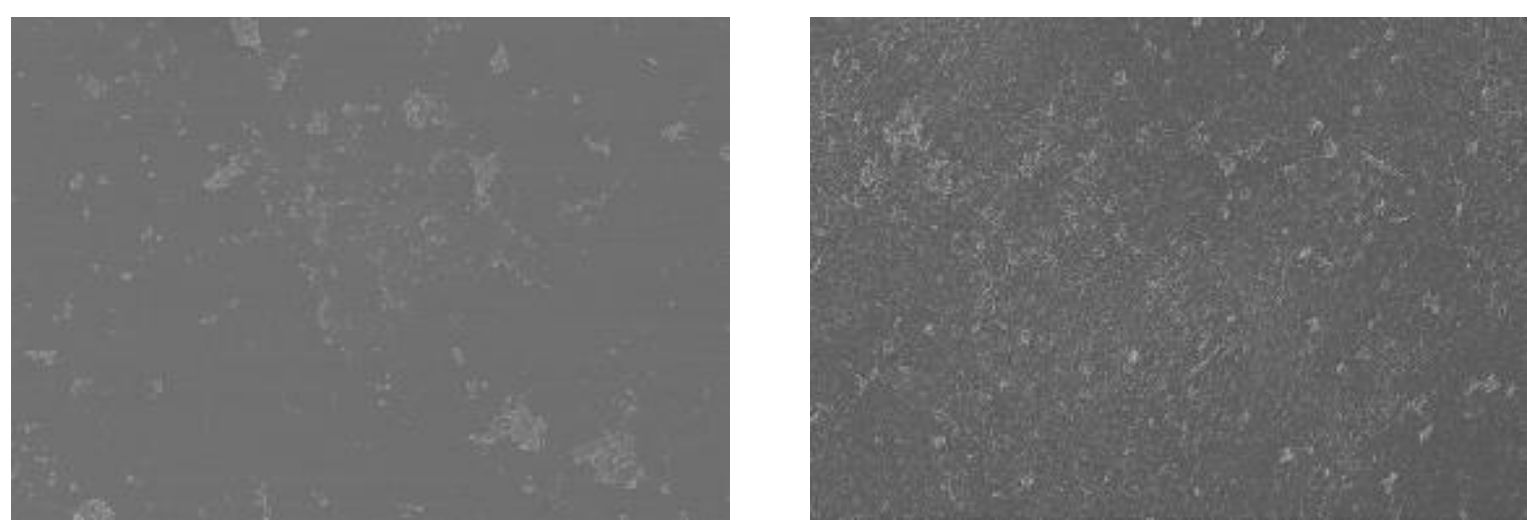

(f) PCL-B10 water

$50 \mu \mathrm{m}$

(j) PCL-B10 soil

$50 \mu \mathrm{m}$

Figure 5. The biofilms formed on the surface of polymers and polymers with tar before biodegradation (a,d) and after biodegradation in water $(\mathbf{b}, \mathbf{c}, \mathbf{e}, \mathbf{f})$ and $(\mathbf{g}-\mathbf{j})$ in soil.

2.2.3. The Effect of Birch Tar Embedded into PLA and PCL on Bacterial Enzymatic Activity

The influence of tar embedded in PLA and PCL on the enzymatic activity of biofilms developed on the surface of the foils is presented in Figure 6. 

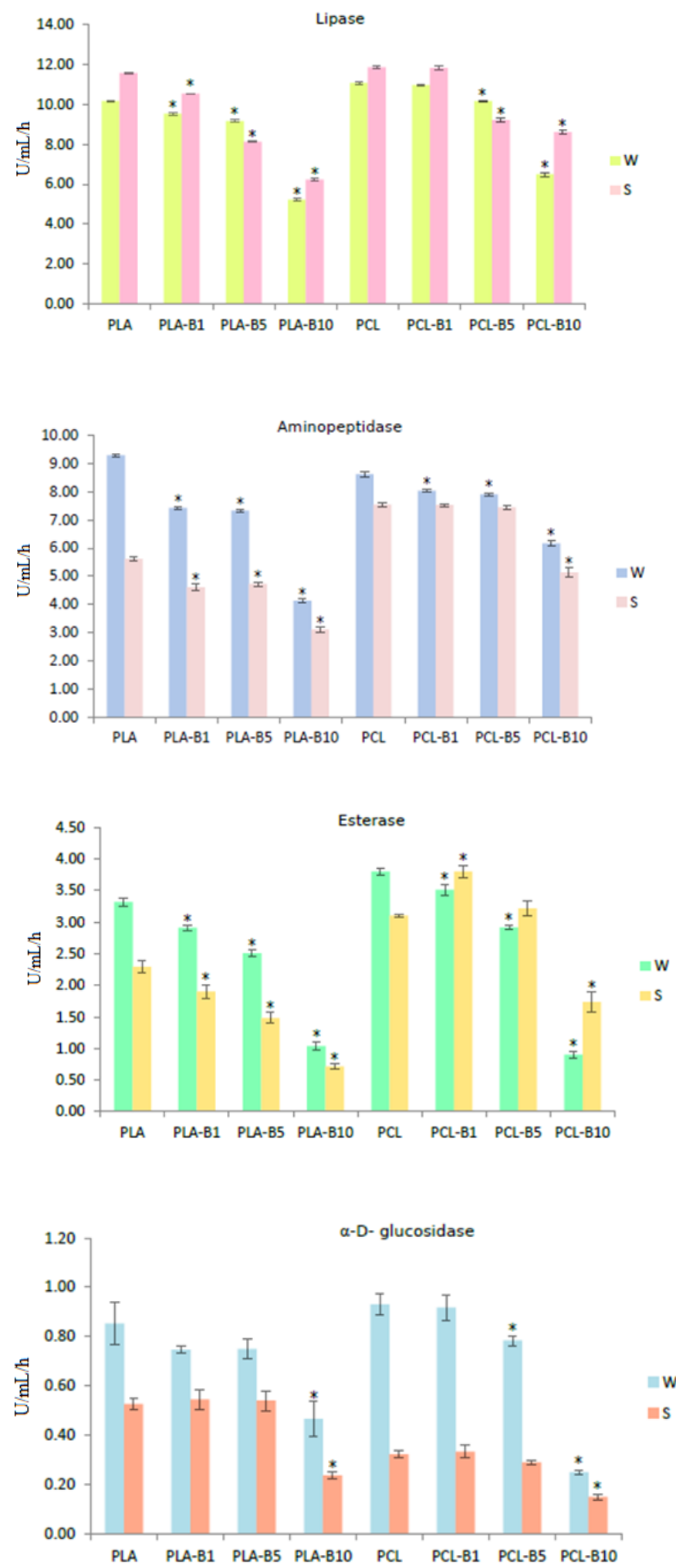

Figure 6. Cont. 


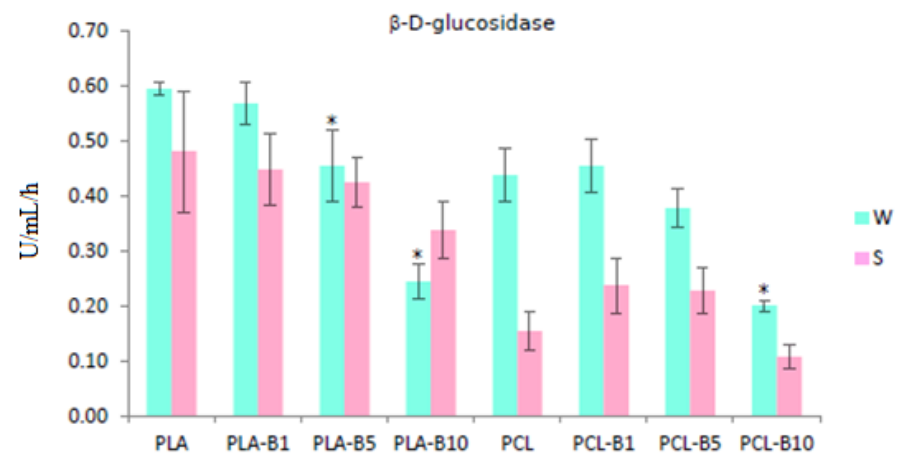

Figure 6. The enzymatic activity (lipase, aminopeptidase, esterase, $\alpha$-D-glucosidase, and $\beta$-Dglucosidase) of biofilm-forming microorganisms on PLA, PCL, and films with birch tar, in river water and soil (* statistical differences).

The data shows that the activity of lipase, aminopeptidase, esterase, $\alpha$-D-glucosidase, and $\beta$-D-glucosidase was affected by the birch tar concentration, and by the environment in which the films were deposited (Figure 6). All the enzymes showed a decrease in activity with an increase of the biocidal compound concentration. This decrease was linear except for $\beta$-D-glucosidase activity in the soil (Table 1). Mann-Whitney test for equal medians for enzyme activities in different materials and environments is presented in Table 2.

Table 1. Least square linear regression analyses of tar concentration and enzyme activities.

\begin{tabular}{ccccccc}
\hline $\begin{array}{c}\text { Film and } \\
\text { Environment }\end{array}$ & Parameter & Lipase & Amino-Peptidase & Esterase & $\alpha$-D-Gucosidase & $\beta$-D-Glucosidase \\
\hline & & & & & & -0.03484 \\
PLA & Slope a: & -0.46306 & -0.44032 & -0.21339 & -0.03393 & 0.60352 \\
water & Intercept b: & 10.365 & 8.8021 & 3.2944 & 0.83987 & 0.93 \\
& $\mathrm{r}^{2}:$ & 0.89 & 0.879 & 0.96 & $<.78$ & $<.0001$ \\
& $p$ & $<0.0001$ & $<0.0001$ & $<0.0001$ & $<0.0001$ & -0.02468 \\
PCL & Slope a: & -0.45022 & -0.22081 & -0.28022 & -0.06753 & 0.46538 \\
water & Intercept b: & 11.467 & 8.5607 & 3.9009 & 0.99011 & 0.85 \\
& $\mathrm{r}^{2}:$ & 0.91 & 0.90 & 0.95 & 0.91 & $<0.0001$ \\
& $p$ & $<0.0001$ & $<0.0001$ & $<0.0001$ & $<0.0001$ & -0.01317 \\
PLA & Slope a: & -0.52075 & -0.20855 & -0.14661 & -0.02737 & 0.47435 \\
soil & Intercept b: & 11.191 & 5.345 & 2.1848 & 0.57113 & 0.43 \\
& $\mathrm{r}^{2}:$ & 0.97 & 0.83 & 0.96 & 0.65 & $<0.05$ \\
PCL & $p$ & $<0.0001$ & $<0.0001$ & $<0.0001$ & $<0.01$ & -0.00737 \\
soil & Slope a: & -0.3543 & -0.23425 & -0.16446 & -0.0178 & 0.2103 \\
& Intercept b: & 11.784 & 7.8487 & 3.6212 & 0.34535 & 0.22 \\
\\
& $\mathrm{r}^{2}:$ & 0.89 & 0.80 & 0.72 & 0.88 & 0.125 \\
\hline
\end{tabular}

Most of the enzymes, except for lipase and aminopeptidase, showed higher activity in soil than in water. The activity of $\beta$-D-glucosidase was significantly higher in biofilm formed at PCL than PLA (Table 2). Among the five hydrolytic enzymes produced by microorganisms within the biofilm, the most active were lipase and aminopeptidase. 
Table 2. Mann-Whitney test for equal medians for enzyme activities in different materials and environments.

\begin{tabular}{cccc}
\hline & Enzyme & Mann-Whitney U & $p$ \\
\hline & Lipase & 178.5 & $<0.05$ \\
PLA vs. PCL & Amino & 122.0 & $<0.01$ \\
& Esterase & 135.5 & $<0.01$ \\
& $\alpha$-D-Glucosidase & 236.0 & $\mathrm{~ns}$ \\
& $\beta$-D-Glucosidase & 105.0 & $<0.001$ \\
& Lipase & 237.0 & $\mathrm{~ns}$ \\
Water vs. Soil & Amino & 139.0 & $<0.01$ \\
& Esterase & 231.5 & $\mathrm{~ns}$ \\
& $\alpha$-D-Glucosidase & 78.0 & $<0.0001$ \\
& $\beta$-D-Glucosidase & 158.5 & $<0.01$ \\
\hline
\end{tabular}

ns-not significant.

\section{Discussion}

Searching for new antibacterial agents that can be embedded into biodegradable materials is still in progress. The innovative polymers developed at the Department of Genetics of the Nicolaus Copernicus University are characterized by sound bactericidal properties, limiting the formation of biofilm. They are also biocompatible and show no genotoxicity and cytotoxicity.

Our previous studies have shown that birch tar incorporated into PLA and PCL films inhibited the growth of bacterial strains such as: E. coli and S. aureus [30,31]. Similarly, Shimizu et al., (2009) [32] showed that birch tar is one of the most effective natural compounds to kill Legionella pneumophila. Probably, the bioactive substances present in tar, such as phenolic compounds, are responsible for its biocidal properties.

New materials containing birch tar were characterized in our previous paper [31] (unpublished). We demonstrated the antibacterial properties of the new polymers as well as their chemical characteristics (water vapor permeability, FTIR, and AFM). In this paper we have focused on the surface analysis of the new PCL and PLA materials showing the structure of foil with the use of SEM as well as its susceptibility to microbial degradation.

Introduction of an antibacterial agent into the PLA-PEG system significantly influences the morphology of the obtained materials. The surface of PLA-based and PCL-based films with an addition of $1 \%$ wt of an antibacterial agent is covered by cracks more intensively than that of a film with a neat polymer matrix. Introduction of a higher content $(5 \%$ and $10 \%$ ) of birch tar into the PLA-PEG and PCL-PEG system results in the formation of holes, cavities and pores evenly distributed throughout the surface. Moreover, it should be emphasized that the number and size of cavities observed on the analyzed surfaces increased with the rise in the amount of the antibacterial agent added to the PLA-PEG and PCL-PEG systems. Interestingly, apart from the increase in the number of cavities, their size was also significantly increased. This can suggest that in the composition of birch bark certain volatile compounds are present which apparently evaporate during the formation of polymeric films. However, based on the extensive study, it was established that there is no single topographic pattern of materials characterized as favorable in terms of bacterial adhesion. Moreover, it was mentioned that, beside surface topography, the shape and size of bacteria substantially influence the interaction between the surface of polymeric material and the bacteria [1].

Heterotrophic microorganisms are present in every environment and their abundance and metabolic activity depends primarily on the amount of easily available organic matter. Bacterial densities in surface freshwaters such as rivers and lakes are usually lower (102-103 cfu/mL) compared to bottom sediments or soils (106-108 cfu/mL) [33]. Degradation of synthetic biopolymers is the outcome of the action of enzymes and acids secreted by microorganisms. Bacteria and fungi with the potential towards the degradation of high molecular weight biopolymers are not common in the environment as compared to microorganisms associated with low molecular weight biodegradable plastics [34]. Yet, their 
abundance is greater in soil than in water. Therefore, we have observed higher biological oxygen demand (BOD) in soil in the presence of tar-containing polymers than in water.

Previous research on biodegradation of PCL and PLA materials showed that several microbial hydrolytic enzymes are engaged in their degradation [35-40]. Our research showed that all the investigated enzymes secreted by microorganisms, both in soil and water, were inhibited in the presence of polymers containing birch tar, which is clearly related to the antibacterial action of tar.

Since information about the mechanism of antibacterial action of birch tar is not yet fully understood, we can only assume that it significantly affects the function of exoenzymes. It has been shown that compounds present in tar such as: phenolic compounds, cresols, allylphenol, guaiacol, 4-methyl- and 4-ethyl guaiacol, eugenol, isoeugenol, vanillin, and ethylvanillin have been identified in biomass pyrolysis of birch. The research by Czernik (2002) showed that phenols in the wood tar constitute up to $20-30 \%$ of its mass [41]. Rohn et al., (2002) showed that enzymes such as $\alpha$-amylase can react with some phenolic compounds and inhibit their activity [42]. The decrease in the activity was accompanied by a reduction in the amount of free amino and thiol groups, as well as tryptophan residues, which resulted from the covalent attachment of the phenolic and related compounds to these reactive nucleophilic sites in the enzymes. Phenolics can also inactivate $\alpha$-glucosidase and lipase through non-specific binding to enzymes [43]. Apart from phenolic compounds, some substances present in birch tar such as eugenol or vanillin have strong antimicrobial properties $[44,45]$.

\section{Materials and Methods}

\subsection{Materials}

Polylactide (PLA) 2003D type (Ingeo Biopolymer 2003D, Nature Works LLC, Minnetonka, MN, USA) with a melt flow rate of $5-7 \mathrm{~g} 10 \mathrm{~min}^{-1}\left(2.16 \mathrm{~kg} ; 190{ }^{\circ} \mathrm{C}\right)$ and a density of $1.24 \mathrm{~g} \mathrm{~cm}^{-3}$ was obtained. Poly(E-caprolactone) (PCL), type CAPA 6800 (Solvay Caprolactones, Warrington, UK), MFI $=7.3 \mathrm{~g} / 10 \mathrm{~min}\left(2.16 \mathrm{~kg}, 160{ }^{\circ} \mathrm{C}\right), \mathrm{Mn} 69 \mathrm{kDa}$, $\mathrm{d}=1.1 \mathrm{~g} / \mathrm{cm}^{3}$. PLA and PCL were in the form of granules which were used to prepare the polymer solutions. Poly(ethylene glycol) (PEG) with Mw $1500 \mathrm{~g} \mathrm{~mol}^{-1}$ (Sigma-Aldrich Ltd., Poznań, Poland) was used as a plasticizer. Chloroform (Chempur, Piekary Sląskie, Poland) was used as a solvent. Birch tar (Betula pendula) (Poland) was used as an "antimicrobial" additive (agent).

\subsection{Preparation of Films}

The examined films were prepared using the solvent-casting method. For this purpose, polylactide pellets were dissolved in chloroform to obtain a $3 \%(w / v)$ polymer solution. Subsequently, $1 \mathrm{wt}$. \%, $5 \mathrm{wt}$. \% and $10 \mathrm{wt}$. \% birch tar were added to the PLA or PCL solution. In total, $5 \mathrm{wt}$. \% PEG was introduced into the solutions to prepare plasticized PLAand PCL-based films and PLA and PCL-birch tar films. To obtain PLA-based materials, $50 \mathrm{~mL}$ of the prepared mixture was poured onto glass Petri dishes $(14.5 \mathrm{~cm}$ in diameter) and left for 3 days to form a polymer film [31,46,47]. All symbols and the composition of the samples were presented in Table 1. The thickness of foils was measured with the use of electronic thickness gauge $0.001 / 0-12.7 \mathrm{~mm}$ Poland. They were in the range from 0.075 to $0.080 \mathrm{~mm}$.

\subsection{Biodegradation of Birch Tar-Containing PLA and PCL}

Biodegradation of PLA and PCL with the embedded wood tar was determined based on the measurement of biological oxygen demand (BOD) with the OxiTop Control (WTW, Wrocław, Poland) according to the method described by Walczak et al., (2015) [48]. Biodegradation of films was studied in two environments, water and soil. The procedure for determining the biodegradation of birch tar containing PLA and PCL films in water was as follows. A $0.5 \mathrm{~L}$ bottle was filled with $430 \mathrm{~mL}$ of river water, a magnetic stirrer was placed inside the bottle, and five drops of nitrification inhibitor NT 600 (WTW, Wrocław, Poland) 
were added. Three fragments of the film $(5 \mathrm{~cm} \times 5 \mathrm{~cm})$, and a rubber carrier containing $\mathrm{CO}_{2}$ absorbent (ca. $0.4 \mathrm{~g} \mathrm{NaOH}$ ) were then inserted into the bottle, and the OxiTop measuring heads were securely fitted. The biochemical oxygen demand was determined at $20{ }^{\circ} \mathrm{C}$ for 14 days. The control samples contained water without films. The samples were analyzed in three replicates. Biodegradation of the film in river water was expressed in $\mathrm{mgO}_{2} / \mathrm{L}$ of water after 14 days of incubation at the temperature of $20^{\circ} \mathrm{C}$. The biodegradation of PLA and PCL in soil was determined with a method modified by Platen and Wirtz (1999) [49]. One hundred grams of soil was placed in the $1 \mathrm{~L}$ jars. Three fragments of each film $(5 \mathrm{~cm} \times 5 \mathrm{~cm})$ were then placed in the soil, and the carriers with absorber $\mathrm{CO}_{2}(0.4 \mathrm{~g} \mathrm{NaOH})$ were mounted to the lid of the jar. The samples were incubated at $20^{\circ} \mathrm{C}$ for 14 days. The control sample was soil without films. Biodegradation of the film in soil was expressed in $\mathrm{mgO}_{2} / \mathrm{kg}$ soil after 14 days at the temperature of $20^{\circ} \mathrm{C}$. All the samples were analyzed in three replicates.

\subsection{Scanning Electron Microscopy}

The morphology of the films containing birch tar (before biodegradation in water and soil) was studied by means of the Quanta 3D FEG scanning electron microscope (SEM, FEI Company, Hillsboro, OR, USA). Photographs of the topography of the samples were taken using the SE detector in 5000-fold magnification. Before each of the analyses, the surfaces of the studied materials were sprayed with a Au layer.

Material structure analysis and biofilm identification on PLA and PCL with birch tar were performed using a scanning electron microscope (HITACHI SU 8010, Hitachi HighTechnologies Co., Tokyo, Japan). The tests were carried out to determine the changes in morphology of the film surface after 7 days of incubation in the compost extract. In order to achieve the best quality photos, the film samples were previously sprayed with a $\mathrm{Au} / \mathrm{Pd}$ alloy. Pictures taken at $1000 \times, 3000 \times$, and $5000 \times$ magnification.

\subsection{Determination of the Effect of Birch Tar on Enzymatic Activity of Biofilm}

The enzymatic activity of biofilm was determined using 4-methylumbelliferyl (MUF) and 7-amido-4-methylcoumarin (AMC)-based substrates: 4-MUF-butyrate for lipase, 4-MUF- $\alpha$-D-glucoside for $\alpha$-glucosidase, 4-MUF- $\beta$-D-glucoside for $\beta$-glucosidase, and L-leucine 7-amido-4-methylcoumarin (AMC) for leucine-aminopeptidase [50]. All the substrates were purchased from Merck (Kenilworth, NJ, USA). Stock solutions of MUF and AMC substrates were prepared in methylcellosolve (ethyleneglycomonomethylether, EGME, Merck). The substrates were dissolved in $10 \mathrm{~mL}$ of methylcellosolve up to a concentration of $3 \mathrm{mM}$ (L:1) and then stored at $-20^{\circ} \mathrm{C}$. Before experimenting, stock solutions were thawed and diluted in sterile deionized water. Esterase activity was determined according to the modified Adam and Duncan method [51]. Titration plates (24-well plates) were used to determine the influence of tar on biofilm formation. Fragments of PLA and PCL $(2 \mathrm{~cm} \times 2 \mathrm{~cm})$ with biofilm formed during incubation in water and soil were placed at the bottom of the well. Furthermore, $2 \mathrm{~mL}$ of broth medium were added and incubated for $24 \mathrm{~h}$ at $20^{\circ} \mathrm{C}$. After the incubation, $0.25 \mathrm{~mL}$ of an appropriate substrate was added to each well (final concentration of $50 \mu \mathrm{mol} / \mathrm{L}$ ). The enzymatic reaction was carried out at $40^{\circ} \mathrm{C}$ for one hour. MUF or AMC concentration was determined using the Hitachi F2500 spectrofluorometer (Tokyo, Japan). One unit of enzyme activity $(\mathrm{U} / \mathrm{mL} / \mathrm{h}$ ) was defined as $1 \mathrm{nmol}$ MUF or AMC released per $\mathrm{ml}$ per $\mathrm{h}$ [52]. To determine the esterase activity, fragments of the films $(2 \mathrm{~cm} \times 2 \mathrm{~cm})$ were placed in titrate plate with broth medium at $20^{\circ} \mathrm{C}$ for $24 \mathrm{~h}$. After adding $50 \mu \mathrm{L}$ of fluorescein diacetate $(1 \mathrm{mg} / \mathrm{mL})$, the plates were incubated at $40{ }^{\circ} \mathrm{C}$ for one hour. The concentration of fluorescein was measured using a HITACHI F2500 spectrofluorometer at a $480 \mathrm{~nm}$ excitation wavelength and $505 \mathrm{~nm}$ emission wavelength. The unit of hydrolase activity was expressed as $\mu \mathrm{g}$ of fluorescein per $\mathrm{ml}$ per hour $(\mathrm{U} / \mathrm{mL} / \mathrm{h})$. All the enzymatic analyses were performed in triplicate. 


\subsection{Statistical Analyses}

All the analyses were performer using Past v. 3.08 (Hammer et al., 2015). The normality of distribution and homogeneity of variances were checked using Shapiro-Wilks and Levene's tests, respectively. To determine the effect of environment (water and soil) and type of the material (PLA and PCL) on respiration, biofilm, and enzyme activity, two-way ANOVA was applied. The least squares regression was performed to predict the behavior of variables mentioned above in relations to the birch tar concentration.

\section{Conclusions}

Tar-containing materials are a promising alternative to plastics containing substances with biocidal properties of chemical origin. The subject of the study was the course of enzymatic degradation of a biodegradable polymer with antibacterial properties. New plastics based on PLA with the addition of tar were produced and their structure was analyzed with the use of SEM. The application of the BOD technique has shown that microorganisms from the aquatic environment and soil are able to grow on tar plastics and to biodegrade them. Tar contained in the films limited the growth of microorganisms, especially those coming from the soil. Microscopic observations of new materials showed the presence of biofilm, which proves the ability of microorganisms to biodegrade the foil with tar. Although a decrease in the activity of hydrolytic enzymes was noted in the presence of films with embedded tar, it was not sufficiently significant to prevent biodegradation, as indicated by measurements of respiration. Additionally, it was shown that biofilm can be formed at the surface of the polymers that gives a future chance for retrieving specific strains of bacteria having the ability to easily decompose such materials that may significantly accelerate their degradation.

\section{Patents}

Richert, A., Dąbrowska, G.B., Dąbrowski, H.P., 2020. Bactericidal polylactide film and the method of its preparation. Patent Application P.433979 (in Polish).

Author Contributions: Conceptualization, A.R.; methodology, A.R.; software, A.R.; validation, A.R.; formal analysis, A.R.; investigation, A.R.; resources, A.R.; data curation, A.R.; writing—original draft preparation, A.R.; writing-review and editing, A.R., A.K., M.S.B. and G.B.D.; visualization, A.R.; supervision, A.R.; project administration, A.R.; funding acquisition, A.R. All authors have read and agreed to the published version of the manuscript.

Funding: The project "Innovation Incubator UMK_4.0" is implemented under the program of the Ministry of Education and Science entitled "Incubator of Innovation 4.0" (contract number MNISW / 2020/331/DIR) as part of the non-competitive project entitled "Support for the management of scientific research and commercialization of the results of R\&D works in research units and enterprises", Intelligent Development Operational Program 2014-2020, Measure 4.4, co-financed by the European Regional Development Fund.

Institutional Review Board Statement: Not applicable.

Informed Consent Statement: Not applicable.

Data Availability Statement: All data is contained within the manuscript.

Conflicts of Interest: The authors declare no conflict of interest.

\section{References}

1. Swiontek, B.M.; Walczak, M.; Kalwasińska, A.; Richert, A.; Świątczak, J.; Deja-Sikora, E.; Burkowska-But, A. Biofilm formation during biodegradation of polylactide, poly(3,4 hydroxybutyrate) and poly(E-caprolactone) in activated sludge. Int. J. Biol. Macromol. 2020, 159, 539-546. [CrossRef]

2. Richert, A.; Dabrowska, G.B. Enzymatic degradation and biofilm formation during biodegradation of polylactide and polycaprolactone polymers in various environments. Int. J. Biol. Macromol. 2021, 15, 226-232. [CrossRef] [PubMed]

3. Sip, A.; Jusik, P. Introducing antimicrobial substances into packaging. Package 2009, 1, 42-47. (In Polish) 
4. Richert, A. Structural and barrier properties of polylactide films with bacteriocins after biodegradation in a compost extract. Przem. Chem. 2017, 96, 1313-1316. (In Polish)

5. Ejaz, M.; Arfat, Y.A.; Mulla, M.; Ahmed, J. Zinc oxide nanorods/clove essential oil incorporated Type B gelatin composite films and its applicability for shrimp packaging. Food Packag. Shelf Life 2018, 15, 113-121. [CrossRef]

6. Gibas, E.; Richert, A. Impact of bacteria on oxy-degradable films containing essential oils and silver, and copper nanoparticles. Przem. Chem. 2018, 97, 291-293. (In Polish)

7. $\mathrm{Xu}, \mathrm{J}$; Zhou, F.; Ji, B.P.; Pei, R.S.; Xu, N. The antibacterial mechanism of carvacrol and thymol against Escherichia coli. Lett. Appl. Microbiol. 2008, 47, 174-179. [CrossRef]

8. Ye, H.; Shen, S.; Xu, J.; Lin, S.; Yuan, Y.; Jones, G.S. Synergistic interactions of cinnamaldehyde in combination with carvacrol against food-borne bacteria. Food Control 2013, 34, 619-623. [CrossRef]

9. Ahmed, J.; Arfat, Y.A.; Bher, A.; Mulla, M.; Jacob, H.; Auras, R. Active chicken meat packaging based on polylactide films and bimetallic Ag-Cu nanoparticles and essential oil. J. Food Sci. 2018, 83, 1299-1310. [CrossRef]

10. Wieczyńska, J.; Cavoski, I. Antimicrobial, antioxidant and sensory features of eugenol, carvacrol and trans-anethole in active packaging for organic ready-to-eat iceberg lettuce. Food Chem. 2018, 259, 251-260. [CrossRef]

11. Richert, J.; Richert, A.; Żenkiewicz, M. Effect of silver nanoparticles on some physic-chemical and biological properties of polyethylene-matrix nanocomposites. Przem. Chem. 2012, 91, 1613-1616. (In Polish)

12. Ahmed, J.; Hiremath, N.; Jacob, H. Antimicrobial efficacies of essential oils/nanoparticles incorporated polylactide films against L. monocytogenes and S. typhimurium on contaminated cheese. Int. J. Food Prop. 2017, 20, 53-67. [CrossRef]

13. Siedenbiedel, F.; Tiller, J.C. Antimicrobial polymers in solution and on surfaces: Overview and functional principles. Polymers 2012, 4, 46-71. [CrossRef]

14. Gijn, A.; Boon, J. Birch bark tar: A Neolithic settlement on the Dutch North Sea coast c. 3500 calbc. Archaeology 2006, 37, 261-266.

15. Kozowyk, P.R.B.; van Gijn, A.L.; Langejans, G.H.J. Understanding preservation and identification biases of ancient adhesives through experimentation. Archaeol. Anthropol. Sci. 2020, 12, 209. [CrossRef]

16. Schmidt, P.; Blessing, M.; Rageot, M.; Iovita, R.; Pfleging, J.; Nickel, G.; Righetti, L.; Tennie, C. Birch tar production does not prove Neanderthal behavioral complexity. Proc. Natl. Acad. Sci. USA 2019, 116, 17707-17711. [CrossRef]

17. Jensen, T.Z.T.; Niemann, J.; Iversen, K.H. A 5700- year-old human genome and oral microbiome from chewed birch pitch. Nat. Commun. 2019, 10, 5520. [CrossRef]

18. Kozowyk, P.R.B.; Soress, M.; Pomstra, D.; Langejans, G.H.J. Experimental methods for the Palaeolithic dry distillation of birch bark: Implications for the origin and development of Neandertal adhesive technology. Sci. Rep. 2017, 7, 8033. [CrossRef]

19. Salonen, J.; Tiilikkala, K.; Ruttunen, P.; Lindqvist, I.; Lindqvist, B. Birch tar oil: A potential herbicide from the forests of Finland. In Proceedings of the Abstracts of the 5th International Weed Science Congress, Weeds Local Problems/Global Challenge, Vancouver, BC, Canada, 23-27 June 2008; pp. 286-287.

20. Tiilikkala, K.; Fagernäs, L.; Tiilikkala, J. History and use of wood pyrolysis liquids as biocide and plant protection product. Open Agric. J. 2010, 4, 111-118. [CrossRef]

21. Tiilikkala, K.; Lindqvist, I.; Hagner, M.; Setälä, H.; Perdikis, D. Use of botanical pesticides in modern plant protection. In Pesticides in the Modern World_Pesticides Use and Management; Stoytcheva, M., Ed.; InTech: London, UK, 2011; pp. $259-272$.

22. Available online: https://pl.wikipedia.org/wiki/Dziegie\%C4\%87_brzozowy (accessed on 15 August 2021).

23. Hagner, M.; Pasanen, T.; Lindqvist, B.; Lindqvist, I.; Tiilikkala, K.; Penttinen, O.-P.; Setala, H. Effects of birch tar oils on soil organisms and plants. Agric. Food Sci. 2010, 19, 13-23. [CrossRef]

24. Hagner, M.; Penttinen, O.; Pasanen, T. Acute toxicity of birch tar oil on aquatic organisms. Agric. Food Sci. 2010, 19, 24-33. [CrossRef]

25. Richert, A.; Dabrowska, G.B. Bacterial biofilm on PLA film and methods of its identification. Ecol. Quest. 2020, 31, 1-13. [CrossRef]

26. Lindqvist, I.; Lindqvist, B.; Tiilikkala, K.; Hagner, M.; Penttinen, O.-P.; Pasanen, T.; Setaälaä, H. Birch tar oil is an effective mollusc repellent: Field and laboratory experiments using Arianta arbustorum (Gastropoda: Helicidae) and Arion lusitanicus (Gastropoda: Aronidae). Agric. Food Sci. 2010, 19, 1-12. [CrossRef]

27. Zhuikov, V.A.; Akoulina, E.A.; Chesnokova, D.V.; Wenhao, Y.; Makhina, T.K.; Demyanova, I.V.; Zhuikova, Y.V.; Voinova, V.V.; Belishev, N.V.; Surmenev, R.A.; et al. The growth of 3T3 fibroblasts on PHB, PLA and PHB/PLA blend films at different stages of their biodegradation in vitro. Polymers 2021, 13, 108. [CrossRef]

28. Sukkhum, S.; Tokuyama, S.; Tamura, T.; Kitpreechavanich, V. A novel poly (L-lactide) degrading actinomycetes isolated from Thai forest soil, phylogenic relationship and the enzyme characterization. J. Gen. Appl. Microbiol. 2009, 55, 459-467. [CrossRef] [PubMed]

29. Donate, R.; Monzón, M.; Alemán-Domínguez, M.E.; Ortega, Z. Enzymatic degradation study of PLA-based composite scaffolds. Rev. Adv. Mater. Sci. 2020, 59, 170-175. [CrossRef]

30. Richert, A.; Dabrowska, G.B.; Dabrowski, H.P. Bactericidal Polylactide Film and the Method of Its Preparation. U.S. Patent Aplication 433,979, 16 September 2020. (In Polish).

31. Richert, A.; Olewnik-Kruszkowska, E.; Dabrowska, G.B.; Dabrowski, H.P. The role of birch tar in changes of physicochemical and biocidal properties of polylactide-based films. Int. J. Biol. Macromol. 2021, 255, 117527.

32. Shimizu, I.; Isshiki, Y.; Nomura, H.; Sakuda, K.; Sakuma, K.; Kondo, S. The antibacterial activity of fragrance ingredients against Legionella pneumophila. Biol. Pharm. Bull. 2009, 32, 1114-1117. [CrossRef] 
33. Swiontek, B.M.; Lalke-Porczyk, E.; Donderski, W.; Walczak, M. Degradation of chitin in natural environment: Role of actinomycetes. Pol. J. Ecol. 2009, 57, 229-238.

34. Castro-Aguirre, E.; Iñiguez-Franco, F.; Samsudin, H.; Fang, X.; Auras, R. Poly(lactic acid)—Mass production, processing, industrial applications, and end of life. Adv. Drug Deliver. Rev. 2016, 107, 333-366. [CrossRef] [PubMed]

35. Sheng, W.; Zhuang, Z.; Gao, M. Correlating hydrogen oxidation and evolution activity on platinum at different $\mathrm{pH}$ with measured hydrogen binding energy. Nat. Commun. 2015, 6, 5848. [CrossRef] [PubMed]

36. Shi, C.; Zhao, X.; Yan, H.; Meng, R.; Zhang, Y.; Li, W.; Liu, Z.; Guo, N. Effect of tea tree oil on Staphylococcus aureus growth and enterotoxin production. Food Control 2016, 62, 257-263. [CrossRef]

37. Khan, S.J.; Abidi, S.N.F.; Skinner, A.; Tian, Y.; Smith-Bolton, R.K. The Drosophila Duox maturation factor is a key component of a positive feedback loop that sustains regeneration signaling. PLoS Genet. 2017, 13, e1006937. [CrossRef]

38. Janczak, K.; Dabrowska, G.B.; Raszkowska-Kaczor, A.; Hrynkiewicz, K.; Richert, A. Biodegradation of the plastics PLA and PET in cultivated soil with the participation of microorganisms and plants. Int. Biodeterior. Biodegrad. 2020, 155, 105087. [CrossRef]

39. Janczak, K.; Hrynkiewicz, K.; Znajewska, Z.; Dąbrowska, G. Use of rhizosphere microorganisms in the biodegradation of PLA and PET polymers in compost soil. Int. Biodeterior. Biodegrad. 2018, 130, 65-75. [CrossRef]

40. Siracusa, V. Microbial degradation of synthetic biopolymers waste. Polymers 2019, 11, 1066. [CrossRef] [PubMed]

41. Czernik, S. Environment, health and safety. In Fast Pyrolysis of Biomass, A Handbook; Bridgewater, A.V., Ed.; CPL Press: Newbury, UK, 2002; pp. 115-118.

42. Rohn, S.; Rawel, H.M.; Kroll, J. Inhibitory effects of plant phenols on the activity of selected enzymes. J. Agric. Food Chem. 2002, 50, 3566-3571. [CrossRef] [PubMed]

43. Zhang, B.; Deng, Z.; Ramdath, D.D.; Tang, Y.; Chen, P.X.; Liu, R.; Liu, Q.; Tsao, R. Phenolic profiles of 20 Canadian lentil cultivars and their contribution to antioxidant activity and inhibitory effects on $\alpha$-glucosidase and pancreatic lipase. Food Chem. 2015, 172, 862-872. [CrossRef] [PubMed]

44. Qian, W.; Sun, Z.; Wang, T.; Yang, M.; Liu, M.; Zhang, J.; Li, Y. Antimicrobial activity of eugenol against carbapenem-resistant Klebsiella pneumoniae and its effect on biofilms. Microb. Pathog. 2020, 139, 103924. [CrossRef]

45. Ribes, S.; Ruiz-Rico, M.; Pérez-Esteve, É.; Fuentes, A.; Barat, J.M. Enhancing the antimicrobial activity of eugenol, carvacrol and vanillin immobilised on silica supports against Escherichia coli or Zygosaccharomyces rouxii in fruit juices by their binary combinations. LWT 2019, 113, 108326. [CrossRef]

46. Olewnik-Kruszkowska, E. Influence of the type of buffer solution on thermal and structural properties of polylactide-based composites. Pol. Degrad. Stab. 2016, 129, 87-95. [CrossRef]

47. Tarach, I.; Olewnik-Kruszkowska, E.; Richert, A.; Gierszewska, M.; Rudawska, A. Influence of tea tree essential oil and poly(ethylene glycol) on antibacterial and physicochemical properties of polylactide-based films. Materials 2020, $13,4953$. [CrossRef]

48. Walczak, M.; Swiontek, B.M.; Richert, A.; Kalwasińska, A. The effect of polyhexamethylene guanidine hydrochlorideon biofilm formation on polylactide and polyhydroxybutyrate composites. Int. Biodeterior. Biodegrad. 2015, 98, 1-5. [CrossRef]

49. Platen, H.; Wirtz, A. Measurement of the Respiration Activity of Soils Using the Oxitop Control Measuring System. Basic Principles and Process Characteristic Quantities; WTW (Wissenschaftlich-Technische Werkstätten): Weilheim, Germany, 1999.

50. Niemi, T.T.; Kuitunen, A.H. Artificial colloids impair haemostasis. An in vitro study using thromboelastometry coagulation analysis. Acta Anaesthesiol. Scand. 2005, 49, 373-378. [CrossRef] [PubMed]

51. Adam, G.; Duncan, H. Development of sensitive and rapid method for the measurement of total microbial activity using fluorescein diacetate (FDA) in a range of soil. Soil Biol. Biochem. 2001, 33, 943-951. [CrossRef]

52. Martinez, J.; Azam, F. Periplasmatic aminopeptidase and alkaline phosphatase activities in a marine bacterium: Implications for substrate processing in the sea. Mar. Ecol. Prog. Ser. 1993, 92, 89-97. [CrossRef] 